\title{
The impact of habitual entrepreneurial experience on new firm closure outcomes
}

\author{
Sandra Gottschalk • Francis J. Greene • \\ Bettina Müller
}

Accepted: 7 June 2016/Published online: 17 August 2016

(C) The Author(s) 2016. This article is published with open access at Springerlink.com

\begin{abstract}
In this paper, we argue that it is difficult for habitual entrepreneurs to use their experiential knowledge to develop a more viable new firm than novice entrepreneurs. Hindered by the difficulty of disentangling how actions lead to outcomes in low predictive environments such as new firm settings; hampered by the novelty and uncertainty of new firm closure; and misguided by subjective beliefs about their ability, we contend that habitual entrepreneurs close their new firm just as quickly as novice entrepreneurs and are just as likely to go bankrupt. Using large-scale panel data that track new firm closure amongst 7400 new German firms, we find that the new firms run by habitual entrepreneurs close just as quickly as those run by novice entrepreneurs. We also find that habituals are just as likely as novices to see their new business go bankrupt.
\end{abstract}

S. Gottschalk · B. Müller

Research Department Economics of Innovation and Industrial Dynamics, Centre for European Economic Research (ZEW), P.O. Box 103443, 68034 Mannheim, Germany

e-mail: Gottschalk@zew.de

B. Müller

e-mail: Bettina.mueller@zew.de

F. J. Greene ( $₫)$

Department of Management, University of Birmingham,

Edgbaston B15 2TT, UK

e-mail: f.greene@bham.ac.uk
Keywords Habitual entrepreneurs - Novice entrepreneurs $\cdot$ Firm closure $\cdot$ Panel data

JEL Classifications $\quad$ L26 $\cdot$ L25

\section{Introduction}

Macmillan (1986) suggests that key to understanding entrepreneurship is better comprehending habitual entrepreneurship. This reflects that habitual entrepreneurship is common (Westhead et al. 2005; Parker 2013) and that habituals (here defined as serial entrepreneurs who previously sold or passed a firm onto a successor, and portfolio entrepreneurs who concurrently run other firms besides the new firm) are distinct from inexperienced novice entrepreneurs in important ways. Chief amongst these is that habitual experience provides valuable experiential learning which augments entrepreneurial ability. ${ }^{1}$ This has led to the notion that habituals perform better in a subsequent new firm than novices (Stuart and Abetti 1990; Starr and Bygrave 1992; Cope 2011).

But is this the case? Are habituals more likely to achieve better outcomes in their new firm than

\footnotetext{
${ }^{1}$ We define ability in terms of causal (i.e. the ability to identify the relationship between cause and effect) rather than procedural (e.g. how well someone performs a task) ability. This is important because enhanced procedural abilities developed through repetition or trial and error may improve the ability to do a task but may not give insights to the reasons why a certain action works or how it can be improved.
} 
novices? In this paper, we argue that there are instances where experience is a poor teacher. Firm behavioural theorists have identified three conditions which make it difficult to apply prior learning successfully in a new business environment. First, there is ambiguity about which actions lead to which outcomes. This causal ambiguity leads individuals to make inferential errors about cause-effect relationships (Levitt and March 1988). Second, individuals are prone to cognitive biases such as over-optimism or over-confidence. The asymmetry between subjective beliefs about ability and actual ability adds to the likelihood of dysfunctional outcomes (Kim et al. 2009). Finally, individuals struggle to identify outcomes because it is difficult to specify the dimensions of success or failure (Zollo 2009). In sum, Levitt and March (1988: 325) define situations in which "the subjective experience of learning is compelling, but the connection between actions and outcomes are misspecified" as superstitious learning.

Our argument in this paper is that although there ought to be gains from experiential learning, it is often difficult to capitalize on prior learning because it is frequently maladaptive in low predictive new firm situations. We see that habituals cannot easily transfer their past entrepreneurial experience to their new firm because outcome uncertainty is high, it is difficult to interpret accurately cause and effect, and because entrepreneurs are prone to cognitive biases such as over-confidence.

To test our theorizing, we investigate the impact of novice and habitual experience on two new firm closure outcomes. First, we focus on the speed of new firm closure. This is important because the extant literature provides divergent accounts of the relationship between habitual experience and the speed of new firm closure: for example, Holmes and Schmitz (1990) suggest that, if prior learning enhances ability, then habituals are better able to persist with their new firm for longer, whilst Arora and Nandkumar (2011) contend that habitual experience alters an entrepreneur's opportunity costs and, as such, habituals may decide to close a firm quicker than novices if it does not meet their performance expectations. Using our maladaptive learning framework, however, we contend that both novice and habitual founders have similar firm closure speeds, suggesting that habitual experience neither lengthens firm persistence, nor leads to the swifter recognition that the firm is unviable.
For our second closure outcome, we distinguish between three other closure outcomes: firm survival, voluntary dissolution and firm bankruptcy. These distinctions are crucial because closure is not a synonym for failure, and can be distinguished into the firm's voluntary dissolution or its bankruptcy (Headd 2003; Bates 2005). They are also important because one presumption is that, if faced with closure, habituals are better able to navigate the firm towards dissolution: habitual experience prompts the redeployment of resources away from the unviable new firm to another yet unrealized later firm or to wage employment, whilst bankruptcy imposes greater costs (Eesley and Roberts 2012). We, however, contend that because of the difficulties in translating experiences from one context to another, novices and habituals are just as likely to experience bankruptcy with their new firm.

To empirically examine the relationship between habitual experience and our two failure outcomes, we use large-scale representative panel data on around 7400 new German firms. These data are valuable for two main reasons. First, these data contain a wide range of other founder, finance and firm-level characteristics. These are clearly important since, for example, a stylized feature of firm closure is that under-resourced firms are more likely to close (Parker 2009; Storey and Greene 2010). A second advantage of these data is that they provide a wider view of the impact of habitual experience than is often offered in other studies. Studies of habitual experience typically focus on venture capital or private equity-backed ventures (Gompers et al. 2010; Arora and Nandkumar 2011). Our data allow us to broaden the perspective because it is representative for the whole population of start-ups in Germany. Moreover, it also allows us to examine-as a robustness check-the impact of habitual experience on the closure outcomes of new firms in high-tech sectors.

Our findings suggest that habituals are just as likely as novice founders to close their firm and go bankrupt. ${ }^{2}$ We also find that these relationships hold when we only focus on high-tech firms. These results, therefore, provide evidence for our theorizing that when habituals and novices face closure, both are liable to superstitious learning.

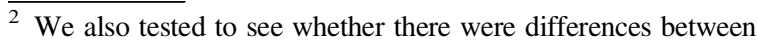
serial and portfolio founders, both in terms of new firm closure speed and bankruptcy likelihoods. There were no qualitative differences. These results are available from the authors on request.
} 
This paper makes three contributions. First, it advances current theorizing on how experiential learning impacts on firm survival outcomes. The presumption in some learning models is that by specializing in entrepreneurship, habituals augment their entrepreneurial ability and are more likely to achieve superior outcomes (Cope 2011; Ericson and Pakes 1995). The inference we draw from our results is that although habituals may learn from experience or suggest that they learn, experiential learning is of little benefit when faced with noisy and complex new firm closure contexts. This is germane since, as Åstebro et al. (2011) and Åstebro and Thompson (2011) show, enterprise populations are also made up of "misfits" and "hobos" as well as "stars". Identifying, therefore, some of the liabilities of habitual experience helps build on prior studies that point to either no effects (Dencker et al. 2009; Ucbasaran et al. 2006) or the negative effects (Tornikoski and Newbert 2007; Frankish et al. 2013) of such experience, thereby extending the understanding of the "darker side" of entrepreneurial learning (Miller 2015). A second contribution is that we use large-scale, fine-grained, longitudinal data. This is important because few studies have access to "a large longitudinal panel database containing a large number of entrepreneurs" (Ucbasaran et al. 2013: 187). Finally, our findings make a practical contribution both for habituals contemplating setting up a new firm and for external stakeholders interested in supporting these entrepreneurs. For example, bank lending is tied to the founder's ability to repay the loan (plus interest). Business closure outcomes, therefore, are key. Having better insights on the role that experience plays in closure outcomes may help banks provide guidance on lending to such groups.

The rest of the paper proceeds as follows. In the next sections, we develop our theoretical framework and develop our hypotheses. We then detail our data, measures and estimation approach. After the results, we conclude by discussing the implications of our findings for scholars, stakeholders and entrepreneurs.

\section{The maladaptive effects of habitual experience}

In the entrepreneurship literature, there has long been the idea that entrepreneurs gain from prior experiential learning because it helps to better estimate ability
(Jovanovic 1982), favourably alters expectations (Frank 1988), or augments ability (Ericson and Pakes 1995). For example, Casson (1999) argues that those with accumulated stocks of knowledge are better placed to deal with market volatility and exogenous shocks because they have greater experience of processing and sifting through information. Minniti and Bygrave (2001) further argue that prior entrepreneurial experience is pivotal in determining outcomes and that "knowledge is cumulative. What is learned in one period builds upon what was learned in an earlier period" (p. 7). Such evidence suggests that entrepreneurial experience promotes the accretion of pathdependent knowledge that can be successfully applied to a new firm.

We note, however, that much of the evidence on the efficacy of habitual experience rests on case studies in which entrepreneurs often self-identify the positive impact of entrepreneurial learning (e.g. Cope 2011; Singh et al. 2015). We also note that applying prior experiential learning is difficult (Levinthal and March 1993). Individuals may learn from experience, but because learning involves the interpretation of these experiences, individuals may struggle to apply prior experiences correctly and appropriately to new situations. We see that such maladaptive learning is highly salient in entrepreneurial settings for three main reasons. First, of particular relevance is that the conditions under which founders make decisions are marked by their rarity, idiosyncrasy and complexity. For example, unlike day-to-day operational issues where there are evident gains from the repetition of tasks (Thompson 2009), developing and implementing strategies to about how to enter a market, thwart the competition, or meet consumer needs are infrequent occurrences. Consequently, this increases the likelihood of founders basing their decisions on small sample sizes which limits opportunities to apply relevant evidence to the current situation (Kim et al. 2009). Inferential errors are also likely because individuals tend to focus on successful rather than unsuccessful outcomes. Denrell (2003) shows that this selection bias leads to inaccurate and faulty inferences about the causes of business performance.

Similarly, no two business situations are identical. Frankish et al. (2013) identify that new and old firms of habitual entrepreneurs differ in significant ways, perhaps because the new firm has a novel product, or because the location or the sector differs. Evidence 
suggests that entrepreneurs find learning to adjust to such changes difficult, particularly because, like everyone else, they are bounded rationalists and prone to satisficing behaviours (Parker 2006). Instead, entrepreneurs prefer to rely on prior learnt routines to guide actions and strategies (Haynie et al. 2012). Related to this is the complexity of the task environment. Entrepreneurship involves orchestrating competing but interdependent activities such as marketing, logistics, financial planning, sales and operations. This makes it extremely difficult to disentangle which actions lead to which particular outcomes. In sum, the rarity, idiosyncrasy and complexity of new firm settings create conditions for causal ambiguity.

Another reason for aberrant learning effects is the presence of cognitive biases such as over-confidence (i.e. the misplaced belief in an individual's ability to achieve a particular outcome, Forbes 2005) or overoptimism (i.e. the tendency to overestimate achieving positive outcomes and under-estimating negative outcomes, Ucbasaran et al. 2010). Studies show that both of these biases are common amongst entrepreneurs (Fraser and Greene 2006; Landier and Thesmar 2009) and persist even in the face of negative information about likely returns from the market (Åstebro 2003). Indeed, such biases help explain why founders over-invest in risky projects, fail to plan for contingencies and starve their new firm of the resources required to achieve sustainability (Hayward et al. 2006).

Finally, Zollo (2009) suggests one further important reason for faulty or false inferences. Alongside conditions that promote causal ambiguity and the asymmetry between subjective beliefs about competency and actual competence, he suggests that it is often difficult to discern outcomes easily. ${ }^{3}$ In new firm settings, such outcome ambiguity is likely because it can be difficult to identify whether or not the opportunity is a plum or a lemon. This outcome fuzziness may be further exacerbated by cognitive biases which cause the founder to overweigh their chances of success and effectively downplay signs of poor performance (Denrell 2003). For example, tenacity may be seen as a virtue if the firm turns out

\footnotetext{
$\overline{3}$ Zollo (2009: 894) defines outcome ambiguity "as the degree of uncertainty related to the assessment of the outcomes consequent to a given decision or to the execution of a given task".
}

to be a success, but it may be a vice, resembling foolish procrastination, if the firm turns out to be a failure. Overall, the combination of causal ambiguity, outcome ambiguity and the presence of cognitive biases such as over-confidence can lead to harmful superstitious learning outcomes in entrepreneurial settings.

\section{Hypotheses}

Our first argument is that, due to superstitious learning, habitual and novice founders are equally likely to speedily close their new firm. Novice entrepreneurs have no entrepreneurial experience and, as such, their past (non-entrepreneurial) experiences may offer poor guidance for decision-making in their new firm. Habituals may believe that their prior experience provides them with a richer competence repertoire, thus equipping them to identify and exploit salient market opportunities (Gruber et al. 2012). Because these experiences proved fruitful before, habituals may replicate these earlier processes of identifying and targeting key customers, competitors and suppliers, believing that it helps shorten the time and resources required to meet important developmental start-up milestones (e.g. making sales, employing staff; Capelleras and Greene 2008). However, because there is significant heterogeneity between businesses, experience gained in one firm is likely to be specific to that firm, resulting in limited opportunities to apply experiential knowledge successfully (Cassar 2014). Indeed, habituals may even mistakenly assume that their prior actions were primarily responsible for the performance of their previous firm when, in fact, it may be that they were simply just lucky or chose a high-risk strategy that paid off (Denrell 2004).

Interpreting noisy prior performance signals may be even harder when there are systematic biases in inferences. Although some studies point to overoptimism declining with experience (Fraser and Greene 2006), other studies show that habituals are prone to over-optimism and over-confidence (Landier and Thesmar 2009; Ucbasaran et al. 2010). Such biases may lead to a strategic myopia whereby the habitual relies on pre-existing opportunity recognition search or firm exploitation strategies that may be illsuited to the current context. This, consequently, is likely to lead to competency traps in which entrepreneurs use strategies previously developed even though 
they are unsuited to the new context. This use of a "square peg" for a "round hole" may undermine firm viability. Indeed, Cassar (2014) shows that experienced entrepreneurs are no better at accurately forecasting their performance than inexperienced entrepreneurs.

Both novices and habituals may be also prone to maladaptive learning when faced with the novelty of firm closure. Faced with a loss-making situation in which they have little experience, it may be difficult for either novices or habituals to discern how their actions relate to the causes of closure and whether or not they are actually facing a closure situation. Hence, buoyed by over-confidence, and given that individuals over-sample instances of success and downplay poor performance, it is likely that both novices and habituals rely on prior, but ill-suited, routines.

In sum, we see that novice and habitual founders face similar maladaptive learning effects. When faced with a context where causal ambiguity is high, novices are likely to draw on non-entrepreneurial experiences. Like habitual founders, we also see that these experiences are likely to be ill-suited to the new firm. Further, one impetus behind going into the new firm is that, as with habituals, novices are likely to be overoptimistic about their likely chances of success and, again, may be subject to similar outcome ambiguities. Hence, we first argue that due to superstitious learning effects:

H1 Habitual entrepreneurs are just as likely to speedily close their new firm as novice entrepreneurs.

One critique of $\mathrm{H} 1$ is that our maladaptive learning framework is not the only explanation for any similarities in firm closure speed. One alternative is that $\mathrm{H} 1$ reflects regression to the mean effects: if past experience is positive, then subsequent outcomes are likely to be closer to the average outcome (closure). Second, although the initial expectation might be that experience prolongs firm persistence (Holmes and Schmitz 1990), ${ }^{4}$ subsequent research identifies countervailing influences on firm closure speed due to "job-matching" effects between the founder and the firm (Holmes and Schmitz 1995). Illustrative of the

\footnotetext{
${ }^{4}$ Holmes and Schmitz Jr (1990: 269) suggest that "those that are subsequently involved in a [business] transfer will on average be of higher 'quality' and also survive than those that are not transferred".
}

importance of these effects is that Gimeno et al. (1997) find that the decision to persist with a firm is impacted by opportunity cost thresholds. If a founder receives low "psychic" (non-pecuniary) benefits from their firm, they may shut it down even if it makes an economic return. However, if the match or psychic benefits are high, the founder is more likely to persist, even if the economic returns are limited. PlehnDujowich (2010) theorizes that although prior experience of business success may prolong firm survival because founders have a more realistic comprehension of opportunities, it may still lead them to cut short the firm and seek alternative options that provide higher returns. Indeed, Arora and Nandkumar (2011) empirically demonstrate that if experienced founders have higher opportunity costs, they are more likely to quickly close their firm if the opportunity does not meet their expected needs. In sum, therefore, an alternative and plausible interpretation of $\mathrm{H} 1$ is that the reason why habituals close their new firm just as quickly as novices is that they realize that it does not meet their expectations.

To better ascertain whether superstitious learning effects are relevant, we therefore propose a further, more stringent, test. We suggest that if the new firm is facing the prospect of closure, both novice and habituals are just as likely to see their new firm go bankrupt. We see that this is valuable because it is difficult to see how, if experience does impact on ability and opportunity costs, a habitual founder would end up in bankruptcy rather than voluntarily dissolution. In these frameworks, experience should make habituals more alert to the dangers they face and make it more likely to husband their resources ready for the next opportunity. Of course, some founders will deliberately choose bankruptcy as a mechanism for sharing risks with creditors. However, the incidence of such actions is very low, with the European Commission (2007) estimating that only 4 per cent of bankrupts attempt to defraud their creditors. Indeed, much more likely, particularly as bankruptcy is a clear sign of business failure (Carter and Van Auken 2006), is that the stigma of bankruptcy vastly outweighs the small chances of deliberate bankruptcy amongst a few novice and habitual founders.

Again core to our argument is that causal ambiguities, cognitive biases and outcome uncertainties lead to maladaptive learning effects that lead both the novice and habitual entrepreneur to be just as likely to 
go bankrupt. Assessing closure outcomes objectively is difficult when no relevant experience is available. In such situations, as we have argued, founders are likely to revert to earlier experiences that may be ill-suited to the firm closure context. This is likely to lead to inferential errors, particularly as founders overgeneralize from examples of success and do not adopt counterfactual thinking. Further exacerbating the presence of causal ambiguity are cognitive biases. For example, whilst habitual founders benefit from greater levels of social and financial capital (Åstbro and Bernhardt 2005) which they can leverage, for example, to attract higher-quality employees, gain trade credit from suppliers and attract outside finance (Eesley and Roberts, 2012; Gompers et al. 2010), one disadvantage of these resource benefits is the expectation that "success" should breed "success". Habituals may believe that by continuing with actions that worked previously, they are more likely to be successful. In doing so, they may persist with actions that do little to turn the fortunes of the firm around and, in fact, lead it further towards bankruptcy.

It may also be difficult for these founders to recognize that the firm is in trouble. Although founders may have developed vicarious learning from observing others, the chances are that these learning experiences, like their own experiences, are likely to oversample and generalize successful contexts. ${ }^{5}$ Accordingly, habituals, like novices, may overestimate their chances of rescuing the new firm, mistaking what is improbable (firm survival) from the more likely (bankruptcy). Furthermore, even if they do recognize that the firm is in difficulties, because individuals become risk lovers in loss situations (Kahneman 2011), habituals are likelyas with novices - to be more prone to risk taking that lead to deleterious outcomes such as bankruptcy (Miller and Chen 2004). In sum, we propose that superstitious learning has negative impacts both for novices and for habituals. Stymied by experiences that are ill-suited to firm closure contexts; hampered by the novelty and uncertainty about likely closure outcomes; and

\footnotetext{
5 Arguably, there may be distinctions that can be drawn between habitual founders, with portfolios being more likely to recognize the prospects of bankruptcy than either serials or novice founders. This may be because they are better able to switch their focus from a failing firm to their other business interests. However, if the focal firm is failing, a reasonable assumption is that other firms owned by the portfolio may also be failing-we thank one of the referees for this valuable last point.
}

misguided by subjective beliefs about their competence, we argue that both are just as likely to go bankrupt. Hence, we write:

H2 Faced with new firm closure, habitual entrepreneurs are just as likely to see their new firm go bankrupt as novice entrepreneurs.

\section{Data and methods}

\subsection{Data}

We use data from five survey waves (2008-2012) of the KfW/ZEW Start-Up Panel (KfW/ZEW-Gründungspanel). These cover new firms founded in the years 2005-2011. The panel was set up in 2008 by the Centre for European Economic Research (ZEW), KfW Bankengruppe (Germany's largest state owned promotional bank) and Creditreform (Germany's largest credit rating agency). Dencker et al. (2009: 1131) point out that "The ZEW panel study data are considered a highly accurate source of statistical information on newly founded firms (all legally independent new firms founded in the private sector) in Germany over time". New firms are sampled from the Mannheim Enterprise Panel (Mannheimer Unternehmenspanel, MUP). The MUP covers almost all firms in Germany and contains annually updated information on the population of new German startups. The information collected in the MUP includes data on firm name and address, legal form, industry classification, start-up and closure dates as well as information on firm dissolution and bankruptcy. One key advantage of these data is that our firm closure outcome measures (survival, dissolution, bankruptcy) are taken from the independent parent MUP data and not from the KfW/ZEW Start-up Panel, thus helping to avoid common-method bias.

The KfW/ZEW Start-up Panel uses the MUP's unique identification code for each firm to sample legally independent new firms. The panel excludes new firms which are the result of merger activities or which are subsidiary businesses and stratifies the sample in three ways: year of firm formation, industry and whether or not the firm received KfW financial support. Each year, a random sample of new firms is drawn from the MUP which has been founded in the 3 years prior to the year of the survey. Firms are 
subsequently followed over successive panel waves until they are 8 years old. These data are collected using computer-aided telephone interviews and have a target of approximately 6000 interviews each year. The 2008-2012 panel waves contain self-reported information on founder characteristics (e.g. educational background, gender, employment status, managerial and leadership experience, entrepreneurial experience) and firm characteristics (e.g. amount of investments and current costs, financing sources and structure, start-up size, number of employees). The total sample is around 11,000 new firms. In this paper, because the data do not allow us to specify whether or not founders have entrepreneurial experience in teambased new firms, we restrict our sample to the 7400 (68\% of total sample) solo founders of new firms.

\subsection{Measures}

\subsubsection{Dependent variables}

In common with a range of other studies (see reviews by Parker 2009; Storey and Greene 2010), we measure survival by recording annually whether or not a firm has survived that specific year $j$. In formal terms, this means that the dependent variable is: $S_{i j}=1$ if firm $i$ survives year $j$ and $S_{i j}=0$ if the firm $i$ does not survive year $j$. In total, as Table 1 shows, $89 \%$ of the focal firms survive. For our second dependent variable, we differentiate the non-surviving firms between those that go bankrupt $(4 \%)$ and those that quit by dissolving their firm $(7 \%){ }^{6}$

\subsubsection{Habitual founders}

In terms of the independent variables central to our analysis, we distinguish between habitual and novice founders by first asking "Have you ever set up one or more firms before the founding of this firm?". If the answer to this was yes, they were then asked whether

\footnotetext{
${ }^{6}$ In Germany, there is a clear distinction between bankrupts and dissolvers: debtors are required to file for bankruptcy if they are financially distressed (i.e. if they are insolvent or cannot pay their debts) (Prantl 2003). Failure to do so is punishable by up to 3 years in jail. German bankruptcy law also does not make provision for voluntarily bankrupt because a German judge will only open bankruptcy proceedings to those that are insolvent or at serious risk of insolvency (i.e. firm bankruptcy is involuntarily, whilst dissolution is for reasons other than bankruptcy).
}

they had either serial or portfolio experience, and if they did, we classified them as habitual founders (see "Appendix" for a list of the definition of the variables). Table 1 shows that $17 \%$ of all founders are habituals.

\subsubsection{Founder human capital characteristics}

Our panel data allow us to control for other factors commonly associated with firm closure. In terms of entrepreneurial characteristics, we consider the highest level of education, industrial and managerial experience since entrepreneurs with higher endowments in these respects are more likely to see their firm survive (van Praag 2003; Lin et al. 2000; Bates 1995). We also control for founder age, gender and start-up motivations (opportunity, necessity and independence). Table 1 shows that $15 \%$ of firm founders are female, that the average age is 41 years and that $30 \%$ has a university degree or a higher vocational qualification, respectively. Mean years of industrial experience are 15 years with $38 \%$ having managerial experience whilst $27 \%$ are motivated by opportunity and a further $19 \%$ set the firm up out of necessity.

\subsubsection{New firm characteristics}

In terms of firm characteristics, we make use of dummies for limited company status and R\&D activity, consider the size of the firms in terms of the number of employees and control for the total amount of investment in the reporting year. ${ }^{7}$ Further, we consider external funding [access to government funding or funding from external investors (share of external financing from investors)], internal financing through sales and retained earnings (share of cash flow on total financing) and whether the firm experienced financial problems. Prior studies show that these factors influence firm survival (Santarelli and Vivarelli 2007; Geroski et al. 2010). Table 1 shows that the average firm size is 3.4 employees (including the founder) with a quarter (26\%) being a limited company and $17 \%$ conducting R\&D. The table also shows that $15 \%$ of founders experienced financial problems; that $35 \%$ used government support; that, on average, $66 \%$ of

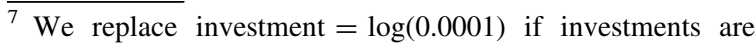
zero; otherwise, we would lose the observation of the firm in the reporting year. We add a control variable indicating that investments are zero for that observation.
} 


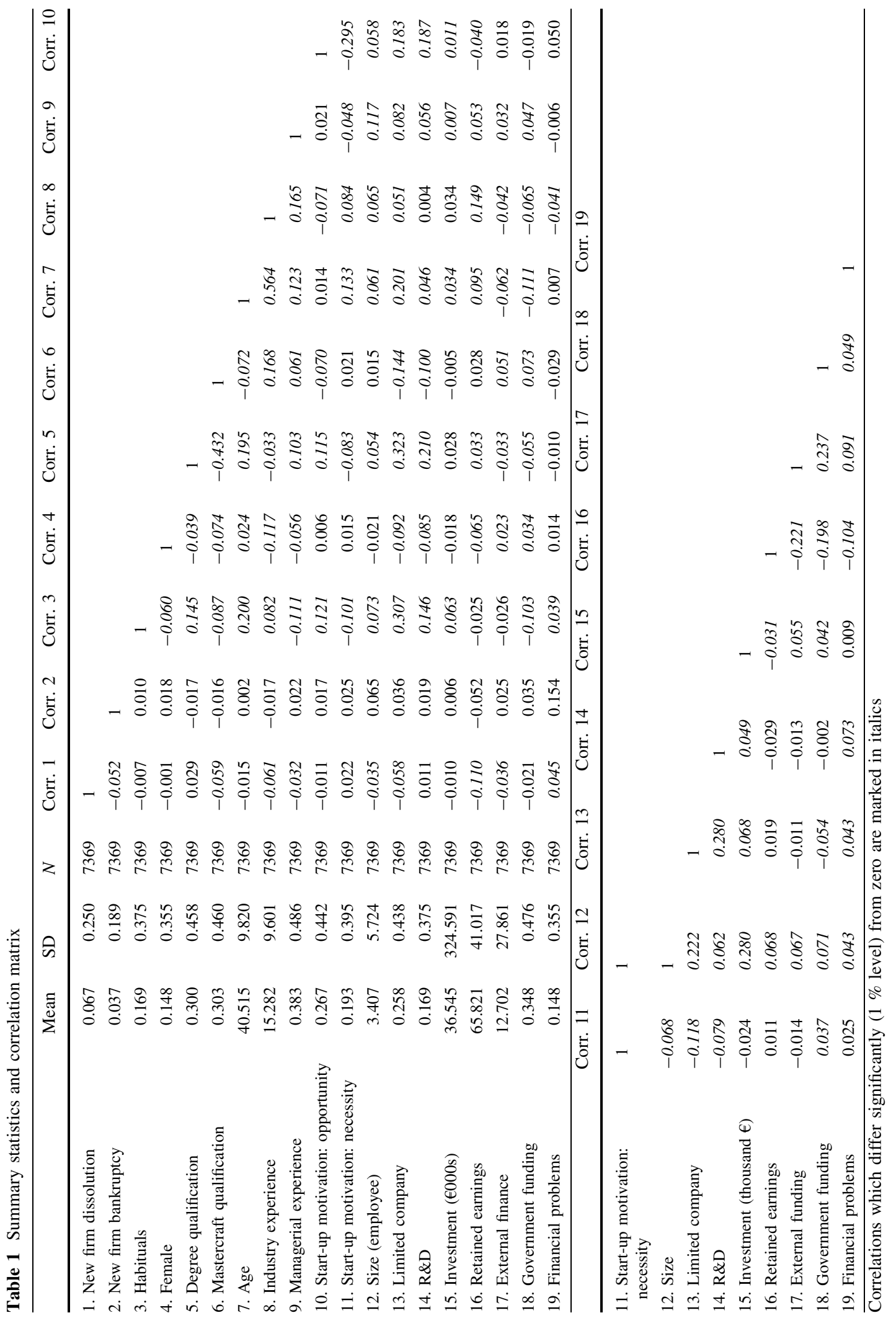


firms used retained earnings to fund their investments; that $13 \%$ used outside financing from external sources (banks, funding or private investors); and that firms invested on average $€ 37,000$ annually.

Finally, we include a range of sector dummies from the standard European Union NACE sectoral classification: new technology-based manufacturing, nonhigh-tech manufacturing, high-tech services, construction, knowledge-intensive services, and consumer-related services, other services and retail, and controls for the start-up year and the reporting year in the estimations (see "Appendix" for definitions). The most common sectors are new technology-based services $(19 \%)$, retail $(17 \%)$, consumer services $(13 \%)$ and construction (13\%), whilst the most common years of founding are 2006 and 2007.

\subsection{Estimation approach}

To identify the length of time a firm survives and if the non-surviving firm either voluntary dissolves or goes bankrupt, we use two duration models. The first is a single risk model where we account for whether or not the firm survives. Whilst survival time is continuous, we estimate a model for interval-censored data because we only observe whether the firm still exists at the end of the year (i.e. spell lengths are only observed in yearly intervals). The relevant hazard rate is the probability of exit during year $j$ given survival up to year $j-1$

$h_{j}(X)=P(j-1<T \leq j \mid T>j-1, X)$,

where $j$ denotes the half-open interval (year ${ }_{j-1} ;$ year $_{j}$ ]. As already mentioned above, the dependent variable contains the information whether or not firm $i$ survived year $j$

$S_{i j}= \begin{cases}1 & \text { if firm } i \text { survives year } j \\ 0 & \text { if firm } i \text { does not survive year } j\end{cases}$

Duration models based on this type of data can be estimated by applying methods for standard binary outcome models (Sueyoshi 1995). As functional form for the hazard rate, we use a complementary log-log specification and allow for both time-invariant and time-variant covariates. ${ }^{8}$ The hazard rate can then be expressed as

\footnotetext{
${ }^{8}$ In principle, any continuous distribution function can be used, but Greene (2000: 815 ) shows that the results of binary choice
}

$\log \left[-\log \left(1-h_{i j}\right)\right]=\beta_{0}+\beta_{1}^{\prime} X_{i}+\beta_{2}^{\prime} Z_{i j}+u_{i}$,

where $X^{\prime}$ is a matrix of time-invariant explanatory variables and $Z_{t}^{\prime}$ is a matrix of time-variant explanatory variables, and $u_{i}$ is the random intercept of firm $i$. In order to allow the hazard rate to vary with survival time (duration dependence), year dummies are added to the list of regressors. To account for at least part of the firm heterogeneity not captured by the observed variables, the complementary log-log model is estimated with random effects so that for binary variables, the unobservable firm effect $u_{i}$ is sampled along with the dependent variable and observable independent variables and it is removed by integrating it out (Wooldridge 2002: 482). Here, the distribution of $u_{i}$ is assumed to be $N \sim\left(0, \sigma_{u}\right){ }^{9}$

Our second duration model is a competing risk model in which we assess whether habitual experience has different impacts on voluntary dissolution and bankruptcy. Because of the way survival time is reported in our data, we again use a model for intervalcensored data. The dependent variable is:

$S_{i j}= \begin{cases}0 & \text { if firm } i \text { survives year } j \\ 1 & \text { if firm } i \text { voluntarily exits in year } j \\ 2 & \text { if firm } i \text { goes bankrupt in year } j\end{cases}$

It can be shown that a competing risk model with interval-censored data can be estimated by applying a standard multinomial logit model. The destinationspecific hazard for the two exit states is:

$h_{\mathrm{vd}}=\frac{\exp \left(\beta_{\mathrm{vd}}^{\prime} X\right)}{1+\exp \left(\beta_{\mathrm{vd}}^{\prime} X\right)+\exp \left(\beta_{\mathrm{b}}^{\prime} X\right)}$

and

$h_{\mathrm{b}}=\frac{\exp \left(\beta_{\mathrm{b}}^{\prime} X\right)}{1+\exp \left(\beta_{\mathrm{vd}}^{\prime} X\right)+\exp \left(\beta_{\mathrm{b}}^{\prime} X\right)}$,

where $\mathrm{vd}=$ voluntary dissolution and $\mathrm{b}=$ bankruptcy. Duration dependence is accounted for by including year dummies in the list of regressors.

Footnote 8 continued

models are not very sensitive to the functional form of the distribution functions.

9 As it is usual with this type of models, we can only control for unobserved firm heterogeneity that does not change over time. 


\section{Results}

We organize our results in four tables. Besides the summary statistics and correlations shown in Table 1, we present in Table 2 univariate $t$ tests to identify whether there are differences between habitual and novices in terms of their human capital and firm characteristics. Table 2 shows that habituals are more likely to be males, university graduates, be older, have more industry experience and be opportunity motivated. In terms of their firm, it is likely to be bigger, have greater investment levels, be a limited company, be more likely to be involved in R\&D and active in high-tech or knowledge-intensive sectors (high-tech manufacturing, new technology-based services, software, knowledge-intensive services) but be less likely to be involved in construction or retail.

Although more habitual founders report experiencing finance problems, getting less government funding and less external financial capital, Table 2 provides a profile of habitual founders that is consistent with them having higher than average human capital attributes and firm-level advantages that are likely to promote superior closure outcomes. Yet, there are no significant differences in the survival and bankruptcy rate between novices and habituals.

These results also appear in the multivariate regressions (Table 3). As column 1 of Table 3 shows, there is no difference between the speed at which habitual and novice founders close their new firm. This supports H1. With respect to the other covariates, we find that there is evidence of an inverted U-shaped pattern effect for entrepreneurial age [age: marginal effect $($ m.e. $)=0.406, \quad p<0.05 ; \quad$ age $^{2}: \quad$ m.e. $=$ $-0.057, p<0.05)$ and that those with mastercraft level qualifications (m.e. $=0.016, p<0.01$ ) and industry experience $(\mathrm{m} . \mathrm{e} .=0.011, p<0.01$ ) are more likely to survive longer. We also find that necessity-motivated founders (m.e. $=-0.012$, $p<0.05$ ) survive for shorter periods and that financial resources influence persistence: founders with greater levels of investment (m.e. $=0.005, p<0.01$ ), received government financial support (m.e. = $0.007, p<0.1)$ and used greater shares of retained earnings (m.e. $=0.0001, p<0.01)$ are all more likely to persist. In contrast, those with financial problems persist for shorter periods (m.e. $=-0.043, p<0.01$ ). In sum, although human capital attributes (e.g. industrial experience and age) and financial resources are important, Table 3 shows that habitual experience has no effect.

Columns 2 and 3 of Table 3 present the marginal effect results of the competing risk model where we compare survival (base category) with dissolution and bankruptcy. We find that habituals are just as likely as novices to dissolve or go bankrupt. This supports $\mathrm{H} 2$. Again there is evidence that other covariates are important in explaining these outcomes. Table 3 shows that necessity-based founders (m.e. $=0.008$, $p<0.01$ ), and those experiencing financial problems (m.e. $=0.023, p<0.01$ ) are more likely to go bankrupt. Those with industrial experience (m.e. $=$ $-0.003, p<0.01$ ), that are graduates (m.e. $=0.006$, $p<0.05)$ or have a higher vocational qualification (mastercraft; m.e. $=0.005, p<0.1$ ) are less likely to go bankrupt.

Although our univariate results showed that habituals are more likely to be R\&D active and in particular high-tech sectors, it may still be the case that very many founders in our sample are lifestyle firms. To examine whether the hypothesized outcomes persist for more innovation-orientated firms, we conducted a robustness check by restricting our sample to hightech firms (new technology-based manufacturing, new technology-based services and software). As Table 4 shows, the marginal effects for prior experience were the same: habitual founders are no more likely to persist with the new firm (column 1: survival time model), nor are they more or less likely to close their firm voluntarily or avoid bankruptcy (column 2 and 3: competing risk model). As with Table 3, Table 4 shows that those with greater levels of industrial experience are able to persist for longer (m.e. $=0.018, p<0.1)$ with their new firm, that graduates are less likely to go bankrupt (m.e. $=-0.008, p<0.1$ ), whilst those who experience financial problems are both more likely to quit sooner (m.e. $=-0.040, p<0.1$ ) and go bankrupt (m.e. $=0.015, p<0.1)$.

\section{Discussion and conclusions}

The two key findings from this study are that habitual and novice founders share similar firm closure speeds and that both are just as likely to see their new firm go bankrupt. These findings persist despite habitual founders having higher levels of human capital (e.g. 
Table 2 Univariate $t$ tests for novice and habitual founders

\begin{tabular}{|c|c|c|c|c|c|}
\hline & \multicolumn{2}{|l|}{ Novices } & \multicolumn{2}{|l|}{ Habituals } & \multirow[t]{2}{*}{ Sig. } \\
\hline & Mean & SD & Mean & SD & \\
\hline Survival rate & 0.896 & 0.305 & 0.896 & 0.244 & \\
\hline Bankruptcy rate & 0.036 & 0.187 & 0.041 & 0.198 & \\
\hline \multicolumn{6}{|l|}{ Founder human capital characteristics } \\
\hline Degree qualification & 0.270 & 0.444 & 0.447 & 0.497 & $* * *$ \\
\hline Mastercraft qualification & 0.321 & 0.467 & 0.215 & 0.411 & $* * *$ \\
\hline Founder's age & 39.627 & 9.617 & 44.870 & 9.646 & $* * *$ \\
\hline Experience in industry & 14.925 & 9.298 & 17.030 & 10.801 & $* * *$ \\
\hline Managerial experience & 0.407 & 0.491 & 0.264 & 0.441 & $* * *$ \\
\hline Female & 0.157 & 0.364 & 0.101 & 0.301 & $* * *$ \\
\hline Motive: opportunity & 0.243 & 0.429 & 0.385 & 0.487 & $* * *$ \\
\hline Motive: necessity & 0.211 & 0.408 & 0.105 & 0.307 & $* * *$ \\
\hline Motive: independence & 0.459 & 0.498 & 0.443 & 0.497 & \\
\hline \multicolumn{6}{|l|}{ New firm characteristics } \\
\hline Number of employees & 3.219 & 4.775 & 4.331 & 8.979 & $* * *$ \\
\hline Financing problem & 0.141 & 0.349 & 0.179 & 0.383 & $* *$ \\
\hline Government funding & 0.370 & 0.483 & 0.240 & 0.427 & $* * *$ \\
\hline Retained earnings & 66.292 & 40.814 & 63.512 & 41.942 & $* *$ \\
\hline External financial capital & 13.032 & 28.245 & 11.086 & 25.846 & $* *$ \\
\hline Investments (thousand $€$ ) & 27.265 & 87.723 & 82.059 & 763.061 & $* * *$ \\
\hline $\mathrm{R} \& \mathrm{D}$ & 0.144 & 0.351 & 0.290 & 0.454 & $* * *$ \\
\hline Limited company & 0.198 & 0.398 & 0.555 & 0.497 & $* * *$ \\
\hline \multicolumn{6}{|l|}{ Sectors } \\
\hline New technology-based manufacturing & 0.088 & 0.283 & 0.119 & 0.324 & $* * *$ \\
\hline New technology-based services & 0.184 & 0.387 & 0.226 & 0.418 & $* *$ \\
\hline Software & 0.049 & 0.217 & 0.084 & 0.278 & $* * *$ \\
\hline Other manufacturing & 0.119 & 0.324 & 0.106 & 0.308 & \\
\hline Knowledge-intensive services & 0.049 & 0.217 & 0.071 & 0.257 & $* *$ \\
\hline Other business services & 0.057 & 0.231 & 0.059 & 0.236 & \\
\hline Consumer services & 0.132 & 0.338 & 0.134 & 0.341 & \\
\hline Construction & 0.147 & 0.354 & 0.067 & 0.251 & $* * *$ \\
\hline Retail & 0.175 & 0.380 & 0.133 & 0.340 & $* * *$ \\
\hline \multicolumn{6}{|l|}{ Foundation years } \\
\hline 2005 & 0.138 & 0.345 & 0.091 & 0.288 & $* * *$ \\
\hline 2006 & 0.170 & 0.376 & 0.128 & 0.334 & $* * *$ \\
\hline 2007 & 0.181 & 0.385 & 0.190 & 0.392 & \\
\hline 2008 & 0.139 & 0.346 & 0.150 & 0.357 & \\
\hline 2009 & 0.147 & 0.354 & 0.175 & 0.380 & $* *$ \\
\hline 2010 & 0.129 & 0.335 & 0.143 & 0.351 & \\
\hline 2011 & 0.096 & 0.294 & 0.123 & 0.328 & $* *$ \\
\hline Number of observations & 6121 & & 1248 & & \\
\hline
\end{tabular}

are graduates), better access to resources, and their firms having more favourable characteristics (e.g. being bigger, limited company status). These are attributes more commonly associated with better survival outcomes. Our results also persist when we examine high-tech firms. 
Table 3 Marginal effects of habitual experience on new firm survival

Dep. var.: survival of the following year $(y / n)$

(1)

Habituals
Female
Degree qualification
Mastercraft qualification

Age

$\operatorname{Age}^{2}$

Industrial experience

Managerial experience

Opportunity

Necessity

Size

Size $^{2}$

Limited company

$\mathrm{R} \& \mathrm{D}$

Investment

Investment dummy

Retained earnings

External funding

Government funding

Financial problems

\section{$-0.002$}

(0.005)

0.001

(0.005)

0.002

(0.004)

$0.016 * * *$

(0.004)

$0.406 * *$

(0.162)

$-0.057 * *$

(0.022)

$0.011 * * *$

(0.002)

$-0.001$

(0.004)

$-0.001$

(0.004)

$-0.012 * *$

(0.005)

$-0.008$

(0.005)

$-0.001$

(0.002)

0.005

(0.005)

$-0.003$

(0.005)

$0.005 * * *$

(0.002)

$0.033 * *$

(0.015)

$0.000 * * *$

(0.000)

0.000

(0.000)

$0.007 *$

(0.004)

$-0.043 * * *$

(0.004)
Dep. var.: survival/voluntary dissolution/bankruptcy of/in the following year

Failure event 1: voluntary dissolution (2)

0.002
$(0.00$
(3)

Failure event 2: bankruptcy

0.001

$-0.002$

(0.003)

0.002

(0.004)

(0.003)

0.004

$-0.006^{* *}$

(0.004)

(0.003)

$-0.005^{*}$

(0.003)

(0.004)

$-0.114$

(0.101)

0.016

(0.014)

$-0.003 * *$

(0.001)

0.004

(0.002)

0.001

(0.003)

$0.008 * * *$

(0.003)

$0.011 * * *$

(0.003)

$-0.001$

(0.001)

$0.009 * * *$

(0.003)

0.003

(0.003)

$-0.002$

(0.001)

$-0.011$

(0.010)

$-0.000$

(0.000)

$-0.000$

(0.000)

$-0.001$

(0.002)

$0.023 * * *$

(0.002) 
Table 3 continued

Dep. var.: survival of the following year $(\mathrm{y} / \mathrm{n})$

(1)
Dep. var.: survival/voluntary dissolution/bankruptcy of/in the following year

Failure event 1: voluntary dissolution

(2)

Failure event 2: bankruptcy

\begin{tabular}{lcc}
\hline Sector dummies & Yes & Yes \\
Cohort dummies & Yes & Yes \\
Firm age dummies & Yes & Yes \\
Number of firms & 7369 & 7369 \\
Number of observations & 15,400 & 15,400 \\
Wald $\chi^{2}(39)$ & $272.46^{* * *}$ & \\
LR $\chi^{2}(78)$ & & $562.58 * * *$ \\
Pseudo- $R^{2}$ & & 0.080 \\
\hline
\end{tabular}

Standard errors in parentheses

$* * *, * *$ * Depict significance at the 1,5 and $10 \%$ level, respectively, and correspond to the test of the underlying coefficient being zero. Reference categories, resp.: formal education: apprenticeship and minor formal education, motive for foundation: independence. For data protection reasons, the coefficient for the explaining variable "financial support by KfW" is not reported in the table

We see that these key focal results are valuable in several ways. First, they challenge the idea of a ready association between habitual experience and firm performance. This theorizing suggests that because entrepreneurship is experiential, habitual experience provides learning opportunities which augment the human capital of habitual entrepreneurs (Cope 2011; Minniti and Bygrave 2001). This leads to predictions that firm survival is more likely or, alternatively, that greater experience increases the chances of speedier firm shut down since habituals are more likely to quickly realize that the new firm does not meet their performance expectations. It also suggests that when faced with closure, greater experience is likely to guide founders away from bankruptcy.

In contrast, our argument is that it is difficult to successfully apply earlier experiences in low predictive new firm environments. In our account, prior performance provides noisy feedback which does little to disentangle the heterogeneous causes of performance. Further, because of biases which lead individuals to overgeneralize experiences of prior success, we argue that this exacerbates the likelihood of behavioural ruts and competency traps which, in the novel context of firm closure, does little to inhibit inferior outcomes such as bankruptcy. This theorizing and our subsequent results, therefore, build on and extend the evidence from a growing number of studies which suggest that habitual experience can lead to costly errors. For example, Parker (2013) finds that habitual entrepreneurship provides only temporary performance effects, whilst other studies, like ours, find that there are few benefits from habitual experience (Frankish et al. 2013; Rocha et al. 2015). Such evidence is valuable because, by pointing to the "darker" side of habitual experience, it helps to correct the prevailing bias towards the assets rather than the liabilities of entrepreneurial experience.

One further advantage of responding to calls for more fine-grained panel data that track the effects of habitual experience on performance (Ucbasaran et al. 2013), is that we are able to examine other pertinent human capital attributes associated with closure outcomes. Our findings show that those with industrial experience are more likely to survive for longer and avoid bankruptcy. This suggests that, although habitual experience provides few opportunities to apply learning in new firm settings, relevant industrial experience increases opportunities for founders to draw on and repeat earlier learning. Specifically, it suggests that industrial experiences reduce uncertainties surrounding the identification and exploitation of an opportunity by giving insights into trends in market segments, and the cost and pricing structures in such markets (Cassar 2014). Equally, our findings also expose two other well-established phenomena: 
Table 4 Marginal effects of habitual experience on new firm survival-high-tech firms (new technology-based manufacturing, new technology-based services, software)

Dep. var.: survival of the following year $(y / n)$

(1)
Dep. var.: survival/voluntary dissolution/bankruptcy of/in the following year

Failure event 1: voluntary dissolution (2)

\begin{tabular}{|c|c|c|c|}
\hline Habituals & $\begin{array}{c}0.005 \\
(0.008)\end{array}$ & $\begin{array}{r}-0.007 \\
(0.008)\end{array}$ & $\begin{array}{c}0.001 \\
(0.004)\end{array}$ \\
\hline Female & $\begin{array}{c}0.001 \\
(0.011)\end{array}$ & $\begin{array}{r}-0.004 \\
(0.009)\end{array}$ & $\begin{array}{c}0.002 \\
(0.005)\end{array}$ \\
\hline Degree qualification & $\begin{array}{r}-0.002 \\
(0.007)\end{array}$ & $\begin{array}{c}0.010 \\
(0.006)\end{array}$ & $\begin{array}{c}-0.008^{* *} \\
(0.004)\end{array}$ \\
\hline Mastercraft qualification & $\begin{array}{c}0.010 \\
(0.008)\end{array}$ & $\begin{array}{r}-0.007 \\
(0.008)\end{array}$ & $\begin{array}{r}-0.003 \\
(0.004)\end{array}$ \\
\hline Age & $\begin{array}{l}0.662 * * * \\
(0.252)\end{array}$ & $\begin{array}{c}-0.470 * * \\
(0.196)\end{array}$ & $\begin{array}{c}0.010 \\
(0.158)\end{array}$ \\
\hline $\mathrm{Age}^{2}$ & $\begin{array}{c}-0.093 * * * \\
(0.034)\end{array}$ & $\begin{array}{l}0.066^{* *} \\
(0.027)\end{array}$ & $\begin{array}{c}0.001 \\
(0.021)\end{array}$ \\
\hline Industrial experience & $\begin{array}{l}0.018 * * * \\
(0.005)\end{array}$ & $\begin{array}{c}-0.015^{* * *} \\
(0.004)\end{array}$ & $\begin{array}{r}-0.003 \\
(0.002)\end{array}$ \\
\hline Managerial experience & $\begin{array}{c}0.002 \\
(0.006)\end{array}$ & $\begin{array}{r}-0.005 \\
(0.006)\end{array}$ & $\begin{array}{c}0.003 \\
(0.003)\end{array}$ \\
\hline Opportunity & $\begin{array}{r}-0.006 \\
(0.007)\end{array}$ & $\begin{array}{c}0.006 \\
(0.006)\end{array}$ & $\begin{array}{r}-0.002 \\
(0.003)\end{array}$ \\
\hline Necessity & $\begin{array}{r}-0.004 \\
(0.008)\end{array}$ & $\begin{array}{c}0.007 \\
(0.007)\end{array}$ & $\begin{array}{r}-0.005 \\
(0.005)\end{array}$ \\
\hline Size & $\begin{array}{c}0.005 \\
(0.009)\end{array}$ & $\begin{array}{r}-0.002 \\
(0.010)\end{array}$ & $\begin{array}{c}0.001 \\
(0.004)\end{array}$ \\
\hline Size $^{2}$ & $\begin{array}{r}-0.001 \\
(0.004)\end{array}$ & $\begin{array}{r}-0.003 \\
(0.005)\end{array}$ & $\begin{array}{r}-0.000 \\
(0.001)\end{array}$ \\
\hline Limited company & $\begin{array}{c}0.003 \\
(0.007)\end{array}$ & $\begin{array}{r}-0.013 * \\
(0.007)\end{array}$ & $\begin{array}{l}0.010 * * * \\
(0.004)\end{array}$ \\
\hline$R \& D$ & $\begin{array}{r}-0.000 \\
(0.007)\end{array}$ & $\begin{array}{r}-0.006 \\
(0.006)\end{array}$ & $\begin{array}{c}0.004 \\
(0.003)\end{array}$ \\
\hline Investment & $\begin{array}{c}0.001 \\
(0.003)\end{array}$ & $\begin{array}{c}0.001 \\
(0.002)\end{array}$ & $\begin{array}{r}-0.000 \\
(0.001)\end{array}$ \\
\hline Investment dummy & $\begin{array}{r}-0.006 \\
(0.025)\end{array}$ & $\begin{array}{c}0.010 \\
(0.021)\end{array}$ & $\begin{array}{c}0.005 \\
(0.013)\end{array}$ \\
\hline Retained earnings & $\begin{array}{c}0.000 \\
(0.000)\end{array}$ & $\begin{array}{r}-0.000 \\
(0.000)\end{array}$ & $\begin{array}{r}-0.000 \\
(0.000)\end{array}$ \\
\hline External funding & $\begin{array}{r}-0.000 \\
(0.000)\end{array}$ & $\begin{array}{r}-0.000 \\
(0.000)\end{array}$ & $\begin{array}{c}0.000 \\
(0.000)\end{array}$ \\
\hline Public funding & $\begin{array}{c}0.008 \\
(0.007)\end{array}$ & $\begin{array}{r}-0.009 \\
(0.006)\end{array}$ & $\begin{array}{c}0.002 \\
(0.003)\end{array}$ \\
\hline Financial problems & $\begin{array}{c}-0.040 * * * \\
(0.008)\end{array}$ & $\begin{array}{l}0.021 * * * \\
(0.007)\end{array}$ & $\begin{array}{l}0.015^{* * * *} \\
(0.003)\end{array}$ \\
\hline
\end{tabular}

Failure event 2: bankruptcy (3) 
Table 4 continued

Dep. var.: survival of the following year $(y / n)$

(1)
Dep. var.: survival/voluntary dissolution/bankruptcy of/in the following year

Failure event 1: voluntary dissolution (2)

Failure event 2: bankruptcy (3)

\begin{tabular}{lcc}
\hline Sector dummies & Yes & Yes \\
Cohort dummies & Yes & Yes \\
Firm age dummies & Yes & Yes \\
Number of firms & 2519 & 2519 \\
Number of observations & 5275 & 5275 \\
Wald $\chi^{2}(33)$ & $115.47 * * *$ & \\
LR $\chi^{2}(66)$ & & $235.25 * * *$ \\
Pseudo- $R^{2}$ & & 0.107 \\
\hline
\end{tabular}

Standard errors in parentheses

***, **, * Depict significance at the 1, 5 and $10 \%$ level, respectively, and correspond to the test of the underlying coefficient being zero. Reference categories, resp.: formal education: apprenticeship and minor formal education, motive for foundation: independence. For data protection reasons, the coefficient for the explaining variable "financial support by KfW" is not reported in the table

necessity founders and financially under-resourced firms are more likely to experience deleterious survival outcomes.

We see that these results have important practical implications. Our findings challenge habituals to carefully evaluate any new opportunity and to examine the routines that they have previously adopted. It also challenges novices to think carefully about the challenges faced by new firm entry. As our study shows, one form of experience that promotes firm survival benefits is relevant industrial experience since this provides valuable and relevant information about opportunities. Moreover, one other potential way of avoiding closure outcomes is to use deliberative forms of learning such as business planning activities that improve decision-making processes in entrepreneurial settings (Burke et al. 2010). We also would join with Ucbasaran et al. (2013) in urging habituals to consider how they make sense of their experiences. We know that cognitive biases are persistent features of entrepreneurial activity and, as such, experienced founders are perhaps better advised to develop heterophily rather than homophily by building firms that rely on diverse teams and outside mentors. This may aid the development of counterfactual thinking and allow for the development of more realistic sensemaking activities about the likelihood of firm closure.
Our findings also have implications for debt financiers. Banks may be persuaded that prior habitual experience is a valuable proxy for a founder's underlying entrepreneurial competence. One potential temptation, therefore, is to target habituals in the belief that they are more likely to repay their loans (plus interest). We do not find support for this strategy: banks are better off focusing on relevant industrial experience and those that do not have financial problems.

Although this study uses large-scale panel data to test whether habituals can learn from their experience, it is subject to a number of caveats. One limitation is that our German habitual new firm founders may be atypical re-entrants. Since we are unable to sample habituals that decided not to return to entrepreneurship, we may be under-estimating the likely experiential learning benefits of prior experience amongst those habitual founders that elect not to re-enter. Rocha et al. (2015), however, do control for selection bias in their Portuguese study and show that habitual experience in itself provides few performance benefits. Further, because our findings relate to habituals as a group, this does not preclude that individual habituals may learn from their experiences and successfully apply these experience in their new firm. Our data are also context specific. It may be that in 
Germany, there are particular reasons for our results, reflecting, for example, German bankruptcy procedures and laws which may incentivize firm founders to act inappropriately or place undue restrictions on the founder which stymie firm survival outcomes, compared to countries such as the USA. In response, we note that in the World Bank Doing Business index, Germany was ranked third out of 184 countries for the ease of its bankruptcy practices. The USA was ranked fifth (World Bank 2015). Nonetheless, it is true that societal attitudes, which we are unable to capture in our data, are likely to influence unobserved attitudes to closure. A stereotypical view is that in the USA, for example, there is a greater acceptance of closure, whilst in Europe, the stigma surrounding new firm closure is more pronounced (Storey and Greene 2010). Whilst we accept that levels of stigma differ between countries, our response is that higher stigma levels in Germany should dissuade individuals from bankruptcy. Further, our study only examines those with habitual experience rather than the nature of these experiences. Hence, our data are silent on how long or how many times these founders were involved in earlier new firms. We note, though, that Greene et al. (2008) found that few founders set up more than two new firms over the course of their entrepreneurial careers. Finally, because we only examine solo founders, we are unable to assess how experiential or vicarious learning gained from prior experience impacts on firm outcomes for team-based entrepreneurship.

We would welcome research that investigated whether founder teams have either more or less difficulties in applying previously acquired knowledge to new situation. Team-based settings may encourage vicarious learning and counterfactual thinking, but it may also lead to "group think" whereby there is a (misguided) consensus about their (superior) competence, what are the (inaccurate) cause-effect relations, and what outcomes are possible (but unlikely). Similarly, although our German study adds to recent British (Frankish et al. 2013) and Portuguese (Rocha et al. 2015) studies that also find habitual experience has little bearing on performance, we see that one way of extending our research is to consider other countries. Another future research direction is to examine firm growth. Survival may be a cardinal business objective for any firm, but scholars, policy makers and practitioners are often keen to establish what factors are likely to promote firm performance. Future research could fruitfully follow our approach by examining, whilst controlling for survivorship bias, whether habitual experience enhances firm performance.

In conclusion, in this paper we argued that it is difficult for habituals to successfully apply their experiential knowledge in another firm so that the new firm is more viable than that of a novice entrepreneur. Using large-scale German panel data that track individual firm founders, we find that both habitual and novice founders have similar firm closure speeds and both are prone to similar bankruptcy outcomes. Such findings are important in challenging the view that habitual experience necessarily leads superior firm closure outcomes.

Acknowledgments We would like to thank the SBE editorial team who were responsible for papers for this special issue. In particular, we would like to thank Mariagrazia Squicciarini and her team as well as an unnamed referee. We would also like to thank Kiran Trehan for her comments on the paper. As usual, all omissions and errors are ours.

\section{Compliance with ethical standards}

Conflict of interest The authors declare that they have no conflict of interest.

Open Access This article is distributed under the terms of the Creative Commons Attribution 4.0 International License (http:// creativecommons.org/licenses/by/4.0/), which permits unrestricted use, distribution, and reproduction in any medium, provided you give appropriate credit to the original author(s) and the source, provide a link to the Creative Commons license, and indicate if changes were made.

\section{Appendix}

See Table 5 . 
Table 5 Variable description

Exit Survival status of the firm at the end of each year-information available in the MUP: 0-active. 1voluntarily closed (liquidated or dissolved). 2-bankruptcy

Habitual experience-available in the KfW/ZEW Start-up Panel

Habitual $\quad 1=$ If either PORTFOLIO $(1=$ founder currently running more than one firm besides the new focal firm) or SERIAL ( 1 = Founder previously sold/transferred a firm)

Founder human capital characteristics-available in the KfW/ZEW Start-up Panel

Degree qualification $\quad 1=$ Founder is a university graduate. $0=$ otherwise

Mastercraft qualification $\quad 1=$ Founder has a German master craftsman diploma. $0=$ otherwise

Age/age $^{2}$

Logarithm of the founders' age in years

Industrial experience

Logarithm of the years of sectoral experience of the founder

Managerial experience

$1=$ Founder has previously been a senior manager in another firm. $0=$ otherwise

Opportunity

$1=$ Main motivation to set up the firm was based on a precise business idea or market gap.

$0=$ otherwise

Necessity

$1=$ Main motivation to set up the firm was because it was a way out of unemployment or the absence of adequate employment. $0=$ otherwise

Independence

$1=$ Main motivation for setting up the firm was to be independent. $0=$ otherwise (base category)

New firm characteristics-available in the KfW/ZEW Start-up Panel

$\mathrm{Size} / \mathrm{size}^{2}$

Limited company

$\mathrm{R} \& \mathrm{D}$

Investments/investment dummy

Retained earnings

External funding

Government funding

Financial problems

Sectors-available in the KfW/ZEW Start-up Panel

New technology-based manufacturing

New technology-based services

Software

Other manufacturing

Knowledge services

Other business services

Consumer services

Construction

Retail

Foundation year

Reporting year dataset) 29.32. 30.20)
Logarithm of number of employees (full-time equivalent) (including the founder)

$1=$ Firm is private or public limited company. $0=$ otherwise (information available from the MUP

$1=$ Firm conducted research and development activities. $0=$ otherwise

Logarithm of the amount of investments (without leasing and rents)/dummy of investments

Percentage share of firm cash flow from sales and retained earnings

Percentage share of financial capital from external sources

$1=$ Received government financial support. $0=$ otherwise

$1=$ Had problems acquiring financial funding from external sources. $0=$ otherwise

$1=$ Firm sector is new technology-based manufacturing. $0=$ otherwise (NACE Rev. 2: 20.20. 21.10. 21.20. 24.46. 25.40. 26.11. 26.20. 26.30. 26.40. 26.51. 26.60. 30.30. 30.40. 32.50/20.13. 20.14. 20.16. 20.17. 20.41. 20.51. 20.53. 20.59. 22.11. 22.19. 23.19. 26.70. 27.11. 27.12. 27.20. 27.40. 27.90. 28.11-15. 28.23. 28.24. 28.29. 28.30. 28.41. 28.49. 28.92-96. 28.99. 29.10. 29.31.

$1=$ Firm sector is new technology-based service industries excluding software. $0=$ otherwise (NACE Rev. 2: 61.1-3. 62 (without 62.01). 63.1. 71.1-2. 72.1)

$1=$ Firm sector is the software industry. $0=$ otherwise (NACE Rev. 2: 62.01)

$1=$ Firm sector is other manufacturing industries other than NTB manufacturing industries.

$0=$ otherwise (NACE Rev. 2: 10-33 (without NTB manufacturing))

$1=$ Firm sector is knowledge-intensive service industries. $0=$ otherwise (NACE Rev. 2: 69.1-2. 70.2. 72.2. 73.1-2)

$1=$ Firm sector is other firm-related service industries. $0=$ otherwise (NACE Rev. 2: 49.2. 49.5. 50.2. 50.4. 51.2. 52. 53. 61.9. 63.9. 64. 74.1. 74.3. 74.9. 77.1. 77.3-4. 78. 80-82)

$1=$ Firm sector is other consumer-related service industries. $0=$ otherwise (NACE Rev. 2: 49.1. 49.3-4. 50.1. 50.3. 51.1. 55. 56. 58-60. 65-66. 68. 74.2. 77.2. 79. 85.5-6. 90-93. 95-96)

$1=$ Firm sector is construction. $0=$ otherwise (NACE Rev. 2: 41-43)

$1=$ Firm sector is the retail sector. $0=$ otherwise (NACE Rev. 2: 45-47 (without 46.1))

Year of firm founding

Reporting year of the survey 


\section{References}

Arora, A., \& Nandkumar, A. (2011). Cash-out or flameout! Opportunity cost and entrepreneurial strategy: Theory, and evidence from the information security industry. Management Science, 57(10), 1844-1860.

Åstbro, T., \& Bernhardt, I. (2005). The winner's curse of human capital. Small Business Economics, 24(1), 63-78.

Åstebro, T. (2003). The return to independent invention: Evidence of unrealistic optimism, risk seeking or skewness loving? The Economic Journal, 113(484), 226-239.

Åstebro, T., Chen, J., \& Thompson, P. (2011). Stars and misfits: Self-employment and labor market frictions. Management Science, 57(11), 1999-2017.

Åstebro, T., \& Thompson, P. (2011). Entrepreneurs, Jacks of all trades or Hobos? Research Policy, 40(5), 637-649.

Bates, T. (1995). Analysis of survival rates among franchise and independent small business startups. Journal of Small Business Management, 33(2), 26-36.

Bates, T. (2005). Analysis of young, small firms that have closed: Delineating successful from unsuccessful closures. Journal of Business Venturing, 20(3), 343-358.

Burke, A., Fraser, S., \& Greene, F. J. (2010). The multiple effects of business planning on new venture performance. Journal of Management Studies, 47(3), 391-415.

Capelleras, J. L., \& Greene, F. J. (2008). The determinants and growth implications of venture creation speed. Entrepreneurship and Regional Development, 20(4), 317-343.

Carter, R., \& Van Auken, H. (2006). Small firm bankruptcy. Journal of Small Business Management, 44(4), 493-512.

Cassar, G. (2014). Industry and startup experience on entrepreneur forecast performance in new firms. Journal of Business Venturing, 29(1), 137-151.

Casson, M. C. (1999). Entrepreneurship and the theory of the firm. In Z. J. Acs, B. Carlsson, \& C. Karlsson (Eds.), Entrepreneurship, small and medium sized enterprises and the macro-economy. Cambridge: Cambridge University Press.

Cope, J. (2011). Entrepreneurial learning from failure: An interpretative phenomenological analysis. Journal of Business Venturing, 26, 604-662.

Dencker, J. C., Gruber, M., \& Shah, S. K. (2009). Pre-entry knowledge, learning, and the survival of new firms. Organization Science, 20(3), 516-537.

Denrell, J. (2003). Vicarious learning, undersampling of failure, and the myths of management. Organization Science, 14(3), 227-243.

Denrell, J. (2004). Random walks and sustained competitive advantage. Management Science, 50(7), 922-934.

Eesley, C. E., \& Roberts, E. B. (2012). Are you experienced or are you talented?: When does innate talent versus experience explain entrepreneurial performance? Strategic Entrepreneurship Journal, 6(3), 207-219.

Ericson, R., \& Pakes, A. (1995). Markov-perfect industry dynamics: A framework for empirical work. Review of Economic Studies, 62, 53-82.

European Commission. (2007). Overcoming the stigma of business failure: For a second chance policy. Brussels: European Commission.
Forbes, D. P. (2005). Managerial determinants of decision speed in new ventures. Strategic Management Journal, 26(4), 355-366.

Frank, M. Z. (1988). An intertemporal model of industrial exit. The Quarterly Journal of Economics, 103, 333-344.

Frankish, J., Roberts, R., Coad A., Spears, T., Storey, D.J., (2013). Do entrepreneurs really learn? Or do they just tell us that they do? Industrial and Corporate Change, 22(1), 73-106.

Fraser, S., \& Greene, F. J. (2006). The effects of experience on entrepreneurial optimism and uncertainty. Economica, 73(290), 169-192.

Geroski, P. A., Mata, J., \& Portugal, P. (2010). Founding conditions and the survival of new firms. Strategic Management Journal, 31(5), 510-529.

Gimeno, J., Folta, T. B., Cooper, A. C., \& Woo, C. Y. (1997). Survival of the fittest? Entrepreneurial human capital and the persistence of underperforming firms. Administrative Science Quarterly, 42(4), 750-783.

Gompers, P. A., Lerner, J., Scharfstein, D., \& Kovner, A. (2010). Performance persistence in entrepreneurship and venture capital. Journal of Financial Economics, 96(1), $18-32$.

Greene, W. (2000). Econometric analysis. Upper Saddle River, NJ: Prentice Hall.

Greene, F. J., Storey, D. J., \& Mole, K. (2008). Three decades of enterprise culture?. London: Palgrave Macmillan.

Gruber, M., MacMillan, I. C., \& Thompson, J. D. (2012). From minds to markets: How human capital endowments shape market opportunity identification of technology start-ups. Journal of Management, 38(5), 1421-1449.

Haynie, J. M., Shepherd, D. A., \& Patzelt, H. (2012). Cognitive adaptability and an entrepreneurial task: The role of metacognitive ability and feedback. Entrepreneurship Theory and Practice, 36(2), 237-265.

Hayward, M. L. A., Shepherd, D. A., \& Griffin, D. (2006). A hubris theory of entrepreneurship. Management Science, 52(2), 160-172.

Headd, B. (2003). Redefining business success: Distinguishing between closure and failure. Small Business Economics, 21(1), 51-61.

Holmes, T. J., \& Schmitz, J. A. (1990). A theory of entrepreneurship and its application to the study of business transfers. Journal of Political Economy, 98, 265-294.

Holmes, T. J., \& Schmitz, J. A. (1995). On the turnover of business firms and business managers. Journal of Political Economy, 103, 1005-1038.

Jovanovic, B. (1982). Selection and evolution in industry. Enonometrica, 50(30), 649-670.

Kahneman, D. (2011). Thinking, fast and slow. New York: Macmillan.

Kim, J. Y., Kim, J. Y., \& Miner, A. S. (2009). Organizational learning from extreme performance experience: The impact of success and recovery experience. Organization Science, 20(6), 958-978.

Landier, A., \& Thesmar, D. (2009). Financial contracting with optimistic entrepreneurs. The Review of Financial Studies, 22(1), 117-150.

Levinthal, D. A., \& March, J. (1993). The myopia of learning. Strategic Management Journal, 14, 95-112. 
Levitt, B., \& March, J. G. (1988). Organizational learning. Annual Review of Sociology, 14, 319-340.

Lin, Z. X., Picot, G., \& Compton, J. (2000). The entry and exit dynamics of self-employment in Canada. Small Business Economics, 15(2), 105-125.

MacMillan, I. C. (1986). To really learn about entrepreneurship, let's study habitual entrepreneurs. Journal of Business Venturing, 1, 241-243.

Miller, D. (2015). A downside to the entrepreneurial personality? Entrepreneurship Theory and Practice, 39(1), 1-8.

Miller, K. D., \& Chen, W.-R. (2004). Variable organizational risk preferences: Tests of the March-Shapira Model. Academy of Management Journal, 47(1), 105-115.

Minniti, M., \& Bygrave, W. (2001). A dynamic model of entrepreneurial learning. Entrepreneurship Theory \& Practice, 25(3), 5-16.

Parker, S. C. (2006). Learning about the unknown: How fast do entrepreneurs adjust their beliefs? Journal of Business Venturing, 21(1), 1-26.

Parker, S. C. (2009). The economics of self-employment and entrepreneurship. Cambridge: Cambridge University Press.

Parker, S.C. (2013). Do serial entrepreneurs run successively better-performing businesses? Journal of Business Venturing, 28(5), 652-666.

Plehn-Dujowich, J. (2010). A theory of serial entrepreneurship. Small Business Economics, 35(4), 377-398.

Prantl, S. (2003). Bankruptcy and voluntary liquidation: Evidence for new firms in East and West Germany after unification (No. 03-72). ZEW Discussion Papers.

Rocha, V., Carneiro, A., \& Varum, C. A. (2015). Serial entrepreneurship, learning by doing and self-selection. International Journal of Industrial Organization, 40, 91-106.

Santarelli, E., \& Vivarelli, M. (2007). Entrepreneurship and the process of firms' entry, survival and growth. Industrial and Corporate Change, 16(3), 455-488.

Singh, S., Corner, P.D., \& Pavlovich, K. (2015). Failed, not finished: A narrative approach to understanding venture failure stigmatization. Journal of Business Venturing, 30(1), 150-166.

Starr, J. A., \& Bygrave, W. D. (1992). The second time around: The outcomes, assets, and liabilities of prior start-up experience. In S. Birley \& I. MacMillan (Eds.), International perspectives on entrepreneurship research ( $\mathrm{pp}$. 340-363). Amsterdam: North Holland.

Storey, D. J., \& Greene, F. J. (2010). Small business and entrepreneurship. London: Pearson/FT.

Stuart, R. W., \& Abetti, P. A. (1990). Impact of entrepreneurial and management experience on early performance. Journal of Business Venturing, 5(3), 151-162.

Sueyoshi, G. (1995). A class of binary response models for grouped duration data. Journal of Applied Econometrics, 10(4), 411-431.

Thompson, P. (2009). Learning by doing. In B. Hall \& N. Rosenberg (Eds.), Handbook of economics of technological change. The Netherlands: Elsevier/North-Holland.

Tornikoski, E. T., \& Newbert, S. L. (2007). Exploring the determinants of organizational emergence: A legitimacy perspective. Journal of Business Venturing, 22(2), 311-335.

Ucbasaran, D., Shepherd, D. A., Lockett, A., \& Lyon, J. (2013). Life after business failure: The process and consequences of business failure for entrepreneurs. Journal of Management, 39(1), 163-202.

Ucbasaran, D., Westhead, P., \& Wright, M. (2006). Habitual entrepreneurs. Aldershot: Edward Elgar.

Ucbasaran, D., Westhead, P., Wright, M., \& Flores, M. (2010). The nature of entrepreneurial experience, business failure and comparative optimism. Journal of Business Venturing, $25,541-555$.

van Praag, C. M. (2003). Business survival and success of young small business Owners. Small Business Economics, 21(1), $1-17$.

Westhead, P., Ucbasaran, D., \& Wright, M. (2005). Decisions, actions, and performance: Do novice, serial, and portfolio entrepreneurs differ? Journal of Small Business Management, 43(4), 393-417.

Wooldridge, J. (2002). Econometric analysis of cross section and panel data. Cambridge, MA: The MIT Press.

World Bank. (2015). Doing business index. http://www. doingbusiness.org/rankings. Accessed 1 Feb 2016.

Zollo, M. (2009). Superstitious learning with rare strategic decisions: Theory and evidence from corporate acquisitions. Organization Science, 20(5), 894-908. 